\title{
TINJAUAN \\ D-ASAM AMINO OKSIDASE DARI MIKROBA: PRODUKSI DAN APLIKASI
}

\author{
A Review \\ Microbial D-amino Acid Oxidase: Production and Application \\ Ahmad Wibisana \& Indria Puti Mustika \\ Balai Pengkajian Bioteknologi BPPT, Gedung 630 Kawasan PUSPIPTEK, \\ Setu, Tangerang Selatan, Banten 15314 \\ E-mail: ahmad.wibisana@bppt.go.id
}

\begin{abstract}
$D$-amino acid oxidase (DAAO) is a flavin adenine dinucleotide-containing enzyme that catalyzes the oxidative deamination of amino acid D-isomers with high stereospecificity, which results in a-keto acids, ammonia and hydrogen peroxide. Having high stereospecificity, DAAO is used in a variety of applications such as drug, biocatalyst, biosensor and preparation of transgenic plants. DAAO is widespread in nature, found in microorganisms to mammals. Microbial DAAO is considered more important than mammalian DAAO for biotechnology application. DAAO production in submerged fermentation is influenced by several factors, such as carbon source, nitrogen source, inducer, dissolve oxygen, temperature and $\mathrm{pH}$. The influence of those factors on DAAO production by microbial origin, DAAO production by microbial recombinant, and its application in biotechnology are discussed in this review.
\end{abstract}

Keywords: Enzyme, DAAO, D-amino acid, production, application

\section{ABSTRAK}

Enzim D-asam amino oksidase (DAAO) merupakan enzim yang mengandung Flavin Adenine Dinucleotide yang bekerja mengkatalisis reaksi oksidasi deaminasi D-asam amino dengan stereospesifisitas yang tinggi menghasilkan $\alpha$-asam keto, amonia dan hidrogen peroksida. Karena mempunyai karakteristik sreteospesifisitas yang tinggi, enzim DAAO banyak digunakan untuk berbagai aplikasi seperti obat, biokatalis, biosensor dan penyiapan tanaman transgenik. Enzim ini dapat dihasilkan oleh organisme mulai dari bakteri hingga mamalia, namun untuk aplikasi dibidang bioteknologi, enzim DAAO yang berasal dari mikroorganisme dipandang lebih penting dari pada yang berasal dari mamalia. Produksi enzim dari DAAO dari mikroorganisme dalam kultur cair dipengaruhi oleh beberapa faktor seperti sumber karbon, nitrogen, senyawa penginduksi, oksigen terlarut, temperatur dan $\mathrm{pH}$ medium. Pengaruh dari faktor-faktor tersebut terhadap produksi enzim DAAO, produksi enzim DAAO menggunakan mikroba rekombinan serta aplikasinya dalam bidang bioteknologi dibahas dalam tinjauan.

Kata Kunci: Enzim, DAAO, D-asam amino, produksi, aplikasi 


\section{PENDAHULUAN}

D-asam amino oksidase ( $D$-amino acid oxidase; DAAO; EC 1.4.3.3,) merupakan enzim yang mengandung flavin adenine dinucleotide (FAD) yang bekerja mengkatalisis reaksi oksidasi deaminasi D-asam amino menghasilkan asam imino dan hidrogen peroksida. Asam imino selanjutnya dengan reaksi non-enzimatis dihidrolisis menjadi a-asam keto dan amonia, sedangkan $\mathrm{FADH}_{2}$ yang terbentuk dioksidasi kembali oleh oksigen menghasilkan hidrogen peroksida (Gambar 1). Enzim DAAO merupakan enzim yang digolongkan dalam sub-grup flavoprotein kelompok dehydrogenase-oksidase, di mana seluruh enzim dalam bentuk tereduksi dapat bereaksi cepat dengan oksigen, menstabilkan radikal anion flavin melalui mekanisme perpindahan satu ion dan menghasilkan flavin N(5)-sulfit (Massey \& Hemmerich 1980).

Enzim DAAO dapat dihasilkan oleh berbagai makhluk hidup mulai dari bakteri hingga manusia dengan fungsi fisiologi yang berbeda-beda. Pada mikroorganisme, enzim DAAO berperan sebagai katabolik (sebagai contoh enzim DAAO diperlukan agar kapang dapat menggunakan D-asam amino untuk tumbuh), sedangkan pada sel mamalia enzim DAAO berperan penting pada tingkat fisiologi asam amino dalam meregulasi berbagai proses metabolisme seperti penuaan, kontrol sinyal saraf, sekresi hormon dan lain sebagainya (Rosini 2009). Tinjauan peran fisiologi enzim DAAO pada berbagai organisme telah dilakukan oleh Pollegioni et al. (2007a). Pada mamalia, enzim DAAO dapat ditemukan di berbagai jaringan, seperti ginjal, hati dan otak. Keberadaan enzim DAAO dalam jaringan mamalia tergantung dari jenis hewannya, sebagai contoh pada babi, enzim DAAO dapat ditemukan di hati dan ginjal, sedangkan pada tikus hanya dapat ditemukan dalam ginjal saja. Berbagai mikroorganisme seperti jamur (Cephalosporium acremonium, Neurosporacrassa, Fusarium solani dan Fusarium oxysporum), alga (Chlorella vulgaris), kapang (Candida tropicalis, Trigonopsis variabilis dan Rhodotorula gracilis) serta bakteri (Alcali-genes denitrificans) mampu menghasilkan enzim DAAO (Saleem 2012).

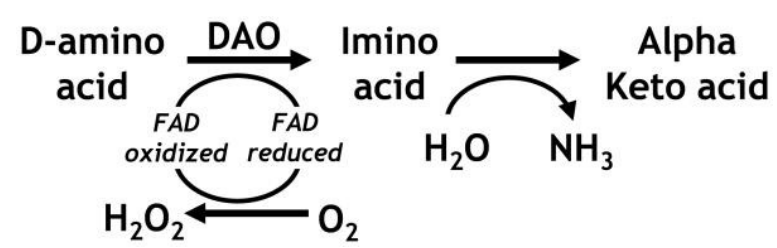

Gambar 1. Siklus katalitik konversi D-asam amino menjadi asam imino yang dikatalisis oleh D-asam amino oksidase dan selanjutnya secara spontan bereaksi menjadi $\alpha$ - asam keto (Verrall 2010)

Tanaman dilaporkan tidak mampu menghasilkan enzim DAAO.

Untuk aplikasi di bidang bioteknologi enzim DAAO yang berasal dari mamalia kurang mendapat perhatian karena jumlahnya sangat sedikit dan bersifat tidak stabil. Enzim DAAO yang dihasilkan oleh mikroorganisme lebih berpotensi untuk aplikasi diberbagai bidang bioteknologi karena mempunyai turnover number yang lebih tinggi, ikatan dengan koenzim yang lebih kuat, gen pengekspresi yang lebih banyak serta mampu menggunakan substrat secara efesien. Hingga saat ini enzim DAAO yang potensial diaplikasikan untuk industri berasal dari Rhodotorula gracilis (RgDAAO) dan Trigonopsis variabilis (TvDAAO), sedangkan dari sumber lainnya secara teknis dianggap kurang penting (Khoronenkova et al. 2008; Sacchi et al. 2004).

Upaya penerapan enzim DAAO dalam industri menghadapi dua permasalahan utama yaitu terkait dengan produktifitas dan stabilitas enzim. Dalam upaya memperoleh mikroba penghasil DAAO baru dengan karakteristik enzim yang lebih baik, maka skrining mikroba penghasil DAAO tetap dilakukan oleh beberapa peneliti. Saleem et al. (2012) melakukan skrining terhadap berbagai spesies jamur (40 spesies) dan memperoleh Fusarium heterosporum dan Nectria haematococca sebagai penghasil enzim DAAO dengan aktifitas tertinggi 210,41 dan 207,94 unit $/ \mathrm{mL}$. Permasalahan stabilitas enzim DAAO terutama terkait dengan konsentrasi protein, oligomerisasi, ikatan ko-faktor dan oksidasi rantai samping asam amino. Peningkatan stabilitas enzim DAAO dapat dilakukan dengan imobilisasi dalam penyangga padat, seperti magnetik, agarose maupun beads epoksi. Peningkatan produktifitas dan stabilitas enzim juga telah dilakukan melalui rekayasa genetika dengan teknik random mutagenesis, error prone $P C R$ maupun mutasi terarah. 


\section{PRODUKSI ENZIM DAAO}

\section{Pengembangan medium produksi DAAO}

Enzim DAAO merupakan metabolit sekunder yang dihasilkan oleh mikroorganisme. Berbagai studi telah dilakukan untuk memperoleh kondisi lingkungan dan komposisi nutrisi yang optimal dari mikroba alami. Produksi enzim DAAO dalam kultur cair dipengaruhi oleh jenis dan konsentrasi sumber karbon, nitrogen, ion logam, senyawa penginduksi (Gupta et al. 2012) dan konsentrasi oksigen terlarut (Gabler \& Fischer 1999). Kondisi lingkungan seperti $\mathrm{pH}$ dan temperatur juga dilaporkan berpengaruh terhadap perolehan enzim DAAO (Saleem et al. 2012; Gupta et al. 2012).

Studi pengaruh jenis sumber karbon terhadap produksi enzim DAAO telah dilakukan dengan menggunakan berbagai monosakarida dan disakarida seperti glukosa, fruktosa, galaktosa, sukrosa, maltosa dan laktosa. Penggunaan monosakarida sebagai sumber karbon untuk produksi DAAO dari $T$. variabilis menghasilkan produktifitas yang lebih tinggi dibanding dengan disakarida dan polisakarida. Diantara monosakarida, glukosa merupakan sumber karbon terbaik untuk menginduksi enzim DAAO (Horner et al. 1996; Ballagi 1999; Prell et al. 2001 \& Gupta et al. 2012). Hal ini menunjukkan penggunaan sumber karbon yang mudah diasimilasi dapat meningkatkan produksi enzim DAAO. Hal yang sama juga dilaporkan untuk produksi DAAO dari $F$. oxysporum (Gabler \& Fisher 1999), Fusarium heterosporum dan Nectria haematococca (Saleem et al. 2012).

Sumber nitrogen juga merupakan salah satu komponen yang esensial dalam medium fermentasi karena berpengaruh terhadap pembentukan asam amino, asam nukleat maupun protein dalam sel mikroba. Penggunaan amonium sulfat sebagai sumber nitrogen dilaporkan dapat menghasilkan produksi enzim DAAO dari $T$. variabilis yang maksimal (Horner et al. 1996; Ballagi 1999; Prell et al. 2001). Hal yang sama juga dilaporkan oleh Gabler \& Fisher (1999) untuk produksi DAAO dari F. oxysporum.

Pengaruh produksi enzim DAAO dari $T$. variabilis yang signifikan juga ditunjukkan oleh penggunaan $\mathrm{Zn}$ sulfat dalam medium produksi. Tanpa penambahan $\mathrm{Zn}$ sulfat, medium produksi yang mengandung glukosa, amonium sulfat dan D-alanin, induksi enzim
DAAO tidak terjadi meskipun sel tetap dapat tumbuh dengan baik seperti pada medium yang mengandung $\mathrm{Zn}$ sulfat. Konsentrasi $\mathrm{Zn}$ sulfat yang diperlukan untuk mencapai kondisi produksi enzim DAAO dan pertumbuhan sel yang baik berkisar antara 20 hinggga $420 \mathrm{mM}$, dan menghasilkan aktifitas spesifik DAAO yang maksimum pada konsentrasi $70 \mathrm{mM}$. Penggunaan $\mathrm{Zn}$ sulfat di atas $280 \mathrm{mM}$ dapat menyebabkan terhambatnya pertumbuhan sel (Horner et al. 1996).

Induksi enzim DAAO dengan menggunakan berbagai jenis asam amino baik yang dapat dimetabolisme maupun turunan asam amino yang tidak dapat dimetabolisme oleh sel juga telah dilaporkan oleh beberapa peneliti. Gabler \& Fischer (1999) melaporkan bahwa D-alanin merupakan senyawa penginduksi terbaik untuk produksi DAAO dari F. oxysporum. Hal yang sama dilaporkan oleh Kuan et al. (2008) untuk produksi enzim DAAO dari $R$. gracilis. Penggunaan D-alanin pada kultivasi $F$. oxysporum mampu meningkatkan aktifitas spesifik enzim DAAO sebesar 13 kali dibandingkan dengan tanpa penggunaan senyawa penginduksi (Gabler \& Fischer 1999). Hal yang menarik adalah induksi DAAO semakin meningkat ketika senyawa penginduksi yang digunakan merupakan campuran antara D dan L-alanin. Perbandingan $D$ dan $L$ alanin yang optimal untuk produksi DAAO adalah 3:1. Dengan pertimbangan faktor ekonomi maka asam amino rasemat $\mathrm{D}, \mathrm{L}$-alanin lebih banyak digunakan sebagai senyawa penginduksi. Berbeda dengan $F$. oxysporum, produksi DAAO dari $T$. variabilis dilaporkan lebih sesuai menggunakan senyawa penginduksi berupa turunan asam amino yang tidak dapat dimetabolisme oleh sel. Dibandingkan dengan induksi DAAO menggunakan D-alanin, penggunaan $\mathrm{N}$-Carbamoyl-D-alanine mampu meningkatkan aktifitas DAAO dalam sel sebesar 4,2 kali (Horner et al. 1996) serta penggunaan 3-(3,4-Dihydroxyphenyl) D,Lalanin meningkatkan sebesar 4,1 kali (Gupta et al. 2012).

Gabler \& Fischer (1999) melaporkan bahwa pembatasan konsentrasi oksigen terlarut pada kultivasi $T$. variabilis dalam fermentasi cair sangat penting. Oksigen terlarut dalam jumlah yang cukup diperlukan pada fase pertumbuhan sel (setelah 12 jam kultivasi) dan menurun menjadi pO2 < 10\% hingga fase stasioner (sekitar jam ke 18). 
Pada fase stasioner DAAO disintesis secara maksimal ketika konsentrasi oksigen berada dalam jumlah yang terbatas serta tersedianya senyawa penginduksi. Hal ini disebabkan karena tejadinya reaksi reoksidasi FAD (kofaktor enzim DAAO) sangat bergantung pada konsentrasi oksigen terlarut. Sel merespon kondisi menurunnya proses asimilasi D-asam amino dan terbatasnya konsentrasi oksigen terlarut dengan meningkatkan sintesis DAAO. Hal ini menyebabkan pertumbuhan sel menjadi terhambat.

Temperatur merupakan faktor yang secara umum berpengaruh terhadap fermentasi. Gabler \& Fisher (1999) melaporkan bahwa produksi DAAO dari $F$. oxysporum mencapai aktifitas DAAO dan pertumbuhan miselia yang maksimum pada temperatur inkubasi $30^{\circ} \mathrm{C}$ dalam waktu 7 hari. Penurunan temperatur inkubasi menjadi $15^{\circ} \mathrm{C}$ atau kenaikan temperatur menjadi $40^{\circ} \mathrm{C}$ mengakibatkan tidak terbentuknya DAAO. Hal yang sama juga dilaporkan untuk produksi DAAO dari T. variabilis (Gupta (2012), F. heterosporum dan N. haematococca (Saleem et al. 2012), sedangkan temperatur optimum untuk produksi DAAO oleh $R$. gracillis dilaporkan pada $37^{\circ} \mathrm{C}$ (Simmonetta et al. 1998).

$\mathrm{pH}$ medium juga sangat berpengaruh terhadap produksi DAAO. Horner et al. (1996) melaporkan bahwa pada kultivasi $T$. variabilis, $\mathrm{pH}$ medium turun dari 6,0 menjadi sekitar 2,2 pada akhir fermentasi. Dengan menggunakan senyawa penginduksi Ncarbamoyl-D,L-alanine serta tanpa perlakuan pengontrolan $\mathrm{pH}$ medium $\mathrm{pH}$ akhir fementasi 2,2), produksi DAAO lebih tinggi jika dibandingkan dengan perlakuan kontrol $\mathrm{pH}$ $(\mathrm{pH}$ medium dikontrol antara 3,8-6,0). Hal ini diduga terkait dengan proses pemanfaatan senyawa penginduksi yang dipengaruhi oleh $\mathrm{pH}$ medium. Pada proses kultivasi dengan perlakuan kontrol $\mathrm{pH}$, sel dapat tumbuh lebih baik, namun enzim DAAO yang dihasilkan lebih sedikit.

\section{Produksi DAAO dari mikroba rekombinan}

Guna meningkatkan produksi enzim, mikroba rekombinan telah digunakan untuk mengekspresikan enzim DAAO. E. coli rekombinan yang dihasilkan dari sistem pT7DAAO mampu mengekspresikan enzim RgDAAO dengan aktifitas volumetrik sebesar
$2300 \mathrm{U} / \mathrm{L}$ dan aktifitas spesifik $930 \mathrm{U} / \mathrm{g}$ sel (Molla et al. 1998). Dengan desain kombinasi gen dan heterologues over-expression RgDAAO dalam Pichia pastoris dapat dihasilkan enzim RgDAAO dengan produktifitas 3,1 kUnit/L.jam dan aktifitas volumetrik mencapai $350 \mathrm{kUnit} / \mathrm{L}$ yang diperoleh melalui fermentasi secara fed-batch (Abad et al. 2011). Dengan menggunakan teknik optimasi bertahap, Pichia pastoris mampu mengekspresikan TvDAAO dengan spesifik aktifitas enzim mencapai $1,3 \mathrm{kU} / \mathrm{g}$ sel kering serta aktifitas volumetrik $218 \mathrm{kU} / \mathrm{L}$ yang diperoleh dengan menggunakan metanol senyawa penginduksi (Abad et al. 2010). TVDAAO yang diekspresikan oleh $E$. coli menggunakan sistem, berturut-turut, pTVDAAO dan pET-DAAO serta senyawa penginduksi IPTG dan laktosa dapat menghasilkan aktifitas enzim 9700 dan 11.700 U/L (Dib et al. 2007; Hwang et al. 2000).

\section{APLIKASI ENZIM DAAO DARI MIKROBA}

Karakteristik utama enzim DAAO adalah spesifisitas kerja yang tinggi terhadap substrat isomer D-asam amino, dan bersifat tidak aktif terhadap substrat isomer L-asam amino (Khoronenkova \& Tishkov 2008; Kuan et al. 2008). Berdasarkan karakteristik tersebut, enzim DAAO banyak digunakan dalam industri untuk memperoleh senyawa enantiomer murni L-asam amino dan $\alpha$ asam keto, sintesis bahan antara 7aminocephalosporanic acid (7-ACA) di industri farmasi dan pembuatan biosensor untuk deteksi D-asam amino guna keperluan analitik maupun klinik (Pollegioni \& Molla 2011). Senyawa $\alpha$-asam keto dan Lasam amino dibutuhkan oleh industri makanan dan farmasi. Sebagai contoh $\alpha$ asam keto digunakan sebagai agen terapeutik untuk pengobatan uremia yang kronik, sedangkan L-asam amino banyak digunakan untuk aditif makanan dan komponen dalam cairan infus.

\section{Produksi senyawa antara 7-ACA}

Aplikasi enzim DAAO yang paling penting adalah penggunaan dalam industri antibiotik untuk proses konversi sefalosporin C menjadi senyawa antara 7-ACA. Proses produksi 7-ACA secara enzimatis mempunyai beberapa keunggulan 


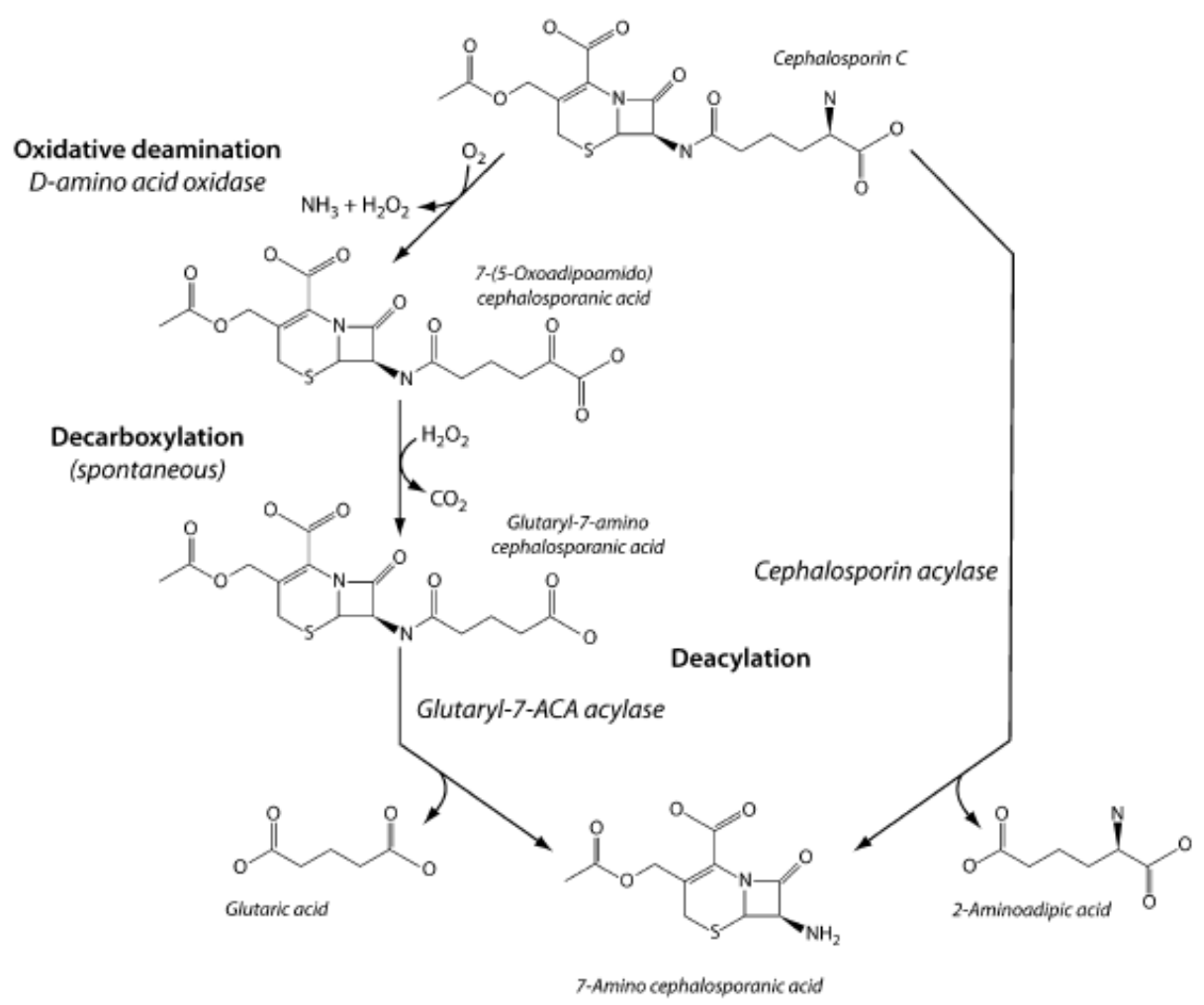

Gambar 2. Konversi sefalosporin C menjadi 7-ACA menggunakan dua tahap reaksi yang melibatkan enzim DAAO dan glutaril-7- ACA asilase (kiri) dan satu tahap reaksi yang dikatalisis oleh enzim sefalosporin asilase (kanan) (Pollegioni 2008)

dibandingkan dengan proses sintesis secara kimiawi. Proses sintesis 7-ACA secara kimiawi memerlukan pelarut organik yang toksik serta membutuhkan banyak tenaga. Sebagai alternatif produksi 7-ACA dapat dilakukan dengan transformasi secara enzimatik melalui dua tahap reaksi (Gambar 2). Tahap I: Reaksi deaminasi sefalosporin $C$ menjadi 7-(5-oxoadipoamido) cephalosporanic acid yang dikatalisis oleh enzim DAAO dan selanjutnya reaksi dekarbosilasi menjadi glutaril 7-ACA terjadi secara spontan dengan adanya $\mathrm{H}_{2} \mathrm{O}_{2}$. Tahap II: Reaksi hidrolisis glutaril 7-ACA menghasilkan 7-ACA dilakukan dengan menggunakan enzim glutaril asilase. Dalam industri biokonversi, enzim DAAO amobil pada umumnya digunakan untuk meningkatkan stabilitas enzim. Imobilisasi enzim DAAO yang dihasilkan oleh $R$. gracilis dengan menggunakan matrik glioksi agarose teraktifasi dapat meningkatkan stabilitas sekitar 15.000 kali (Betancor et al. 2003). Proses biokonversi yang dikatalisis oleh enzim DAAO juga dapat dilakukan dengan menggunakan sel utuh. Faktor pembatas yang berupa hambatan difusi substrat ke dalam sel dapat diatasi dengan teknik permeabilisasi sel. Kelemahan utama penggunaan sel utuh adalah adanya enzim yang lain seperti katalase dan esterase yang dapat menurunkan baik perolehan maupun kualitas produk glutrail 7-ACA.

\section{Sintesis L-asam amino dan $\alpha$-asam keto}

Karakteristik enzim DAAO yang mempunyai spesifitas tinggi terhadap Dasam amino dapat dimanfaatkan untuk produksi $\alpha$-asam keto maupun pemurnian Lasam amino dari campuran rasemik D,Lasam amino. Senyawa $\alpha$-asam keto dan asam amino non-alami yang murni secara optik telah mendapat perhatian sejak lama oleh industri kimia dan farmasi, khususnya untuk penemuan obat.

Enzim DAAO dari hati babi (pkDAAO) digunakan pertama kali pada tahun 1971 untuk membuat L-pipecolic acid dari campuran rasemik melalui oksidasi Disomer. L-pipecolic acid merupakan senyawa antara hasil katabolisme L-Lisin dari organisme yang mengalami kondisi disfungsi peroksisom (Tranchant et al. 1993). Asam amino ini mempunyai peranan yang sangat penting terutama yang berkaitan dengan penyakit pada sistem saraf (Plecko et al. 
2005). Berbagai turunan L-pipecolic acid disintesis untuk digunakan sebagai obat neuroprotektif, imunodepresan dan antikanker (Maddess 2008). Pada perkembangan terakhir, enzim DAAO dari $T$. variabilis dan $R$. gracilis digunakan untuk menggantikan enzim DAAO dari hati babi.

Senyawa penting dalam industri farmasi lainnya adalah 4-Methylthio-2oxobutyric acid (MTOBA). Sebagai prekursor metabolit dari senyawa methional, yaitu senyawa penginduksi yang kuat untuk proses apoptosis, MTOBA dapat digunakan sebagai obat antikanker. Pada sel kanker yang bersifat methionine-dependent, kandungan MTOBA lebih kecil dibandingkan dengan sel normal. Sintesis MTOBA dapat dilakukan dari oksidasi deaminasi dari $D$ metionin. Metode terbaru yang lebih ekonomis untuk produksi MTOBA adalah berdasar pada pengolahan campuran rasemik D,L-metionin (Garcia-Garcia 2008).

Senyawa penting lainnya yang dihasilkan dengan menggunakan enzim DAAO adalah L-6-hydroxynorleucine. Senyawa kiral ini digunakan untuk sintesis Omapatrilat dan seluruh seri inhibitor metalloproteinase (Patel 2001). Omapatrilat adalah inhibitor dari enzim pengkonversi angiotensin dan endopeptidase netral sehingga efektif digunakan sebagai obat antihipertensi (Patel 2001). Produksi L-6hydroxynorleucine stereoisomer dapat dilakukan menggunakan bahan baku campuran rasemik 6-hydroxynorleucine sebagai (Taylor 1998).

L-asam amino yang mengandung kelompok naptalen banyak digunakan untuk pengembangan obat baru. Sebagai contoh L-2-naphthylalanine merupakan komponen dari obat peptide Naferelin (Caligiuri 2006a). Asam amino ini dapat dihasilkan dari campuran rasemik 2-naphthylalanine, dengan melibatkan tiga enzim, yaitu RgDAAO, katalase, dan L-aspartate aminotransferase (Caligiuri 2006b).

Perkembangan terbaru potensi aplikasi senyawa D-asam amino untuk terapeutik adalah sebagai antibakteri, antijamur dan aktifitas sitotoksitas. Aktifitas antibakteri dari beberapa senyawa $D$-asam amino yaitu $D$ alanin, D-lisin, D-serin dan D-prolin telah diuji terhadap berbagai patogen, yaitu Bacillus subtilis ATCC 11562, Staphylococcus aureus ATCC 6538,
Staphylococcus epidermidis ATCC 12228, Escherichia coli ATCC 29425, Pseudomonas aeuriginosa ATCC 11921 dan Xanthomonas vesicatoria ATCC 11633. Aktifitas antibakteri dari asam amino di atas dilaporkan relatif rendah, dengan nilai konsentrasi hambat minimum (KHM) berada dalam rentang milimolar. Aktifitas antibakteri tertinggi ditunjukkan oleh D-lisin diikuti oleh D-alanin (Sanaa 2014). Hal yang menarik adalah penggunaan D-asam amino yang dikombinasikan dengan antibiotik lain sebagai antibakteri menunjukkan hubungan yang sinergistik sehingga meningkatkan aktifitas antibakteri. Kombinasi D-lisin dan Dalanin dengan sodium sefuroksim dilaporkan dapat menurunkan KHM dengan rentang berturut-turut antara 5,0-6,5 kali dan 3,7-5,3 kali terhadap bakteri uji yang digunakan. Aktifitas antijamur dari D-lisin dan D-alanin juga dievaluasi terhadap Candida albicans, salah satu patogen utama penyebab infeksi nosokomial. Kedua asam amino menunjukkan aktifitas antijamur yang moderat dengan KHM berturut-turut, 39 dan $18 \mu \mathrm{g} \mu \mathrm{L}^{-1}$. Kombinasi kedua asam amino dengan ampoterisin $\mathrm{B}$ mampu menurunkan KHM sebesar 6 kali.

\section{Biosensor}

Enzim DAAO juga telah dimanfaatkan sebagai biosensor untuk deteksi D-asam amino yang dihasilkan oleh organisme. Meskipun analisa D-asam amino dengan metode kromatografi telah menghasilkan metode yang sensitif, tepat dan akurat, namun mempunyai kelemahan yaitu memerlukan waktu lama, peralatan mahal dan metode yang sulit. Oleh karena itu deteksi D-asam amino yang berbasis pada kerja enzim DAAO sangat diperlukan untuk keperluan analitik maupun klinik (Pilone \& Pollegioni 2010). Di bidang kesehatan, deteksi D-asam amino dalam tubuh dapat digunakan sebagai indikator berbagai penyakit yang terkait dengan kelainan fungsi syaraf dan psikiatrik seperti scizoprenia (Chumakov et al. 2002; Hashimoto et al.2003; Tsai et al. 2006; Bendikov et al. 2007), iskemia, epilepsi dan nyeri kronik yang disebabkan oleh saraf (Zhao et al. 2010). Di bidang pangan, biosensor yang bekerja berdasar atas enzim DAAO telah digunakan untuk deteksi kontaminasi makanan oleh bakteri. D-asam amino 
merupakan komponen peptidoglikan dari dinding sel bakteri sehingga keberadaannya dalam makanan dapat digunakan sebagai indikator terjadinya kontaminasi oleh bakteri (Sacchi et al. 2004).

\section{Enzim DAAO untuk bidang pertanian}

Dalam bidang pertanian, kontribusi penting bioteknologi terkait dengan tanaman transgenik. Tanaman mempunyai kemampuan yang terbatas dalam metabolisme D-asam amino, tetapi dapat menyerap D-asam amino yang berasal dari lingkungan. Karena sel tanaman tidak mempunyai enzim DAAO indigenous maka akumulasi D-asam amino dalam tanaman akan meningkat sehingga mengakibatkan terhambatnya pertumbuhan tanaman (Erikson et al. 2004). Guna mengatasi masalah tersebut, tanaman transgenik Arabidopsis thaliana yang dapat mengekspresikan RgDAAO telah berhasil dikembangkan Erikson et al. (2004). Tanaman transgenik ini mampu mengkonversi $\mathrm{D}$-asam amino menjadi $\mathrm{D}$ asam $\alpha$-keto yang tidak berbahaya bagi tanaman sehingga pertumbuhan tanaman tidak terhambat. Sistem ini telah dikonfirmasi menggunakan tanaman transgenik padi, dan dilaporkan bahwa ekspresi TvDAAO ke dalam tanaman tidak menimbulkan abnormalitas tanaman (Lin et al. 2009).

\section{KESIMPULAN}

DAAO merupakan enzim yang penting untuk aplikasi di bidang bioteknologi pangan, kesehatan maupun pertanian. Potensi aplikasi enzim DAAO terus berkembang seiiring dengan ditemukannya berbagai aplikasi baru. Pada awalnya enzim DAAO dihasilkan dari ginjal babi, sehingga tidak sesuai untuk aplikasi dalam skala besar. Sebagai alternatifnya, DAAO dapat dihasilkan dengan menggunakan mikroba. Selain dapat mengatasi masalah yang terkait dengan keekonomian, enzim DAAO dari mikroba juga menunjukkan karakteristik yang lebih baik, seperti produktifitas dan stabilitas enzim. Dengan memanfaatkan bioteknologi modern melalui rekayasa genetika dan pemahaman fungsi struktur yang lebih baik, maka diharapkan dapat dihasilkan varian baru enzim DAAO dengan karakteristik yang baru.

\section{DAFTAR PUSTAKA}

Abad S, Nahalka J, Bergler G, Arnold SA, Speight R, Fotheringham I, Nidetzky B, Glieder A (2010) Step wise engineering of a Pichia pastoris Damino acid oxidase whole cell catalyst. Microb Cell Fact 9:1-12

Abad S, Nahalka J, Winkler M, Bergler G, Speight R, Glieder A, Nidetzky B (2010) High-level expression of -amino acid oxidase in Pichia pastoris. Biotechnol Lett 33:557-563

Ballagi A (1999) High cell densityfermentation of Trigonopsis variabilis with D-amino acid oxidase production. M.Sc. Thesis, Biochemistry and Biotechnology Department, The Technical University of Braunschweig

Bendikov I, Nadri C, Amar S, Panizzutti R, De Miranda J, Wolosker H, Agam G (2007) A CSF and postmortem brain tudy of D-serine metabolic parameters in schizophrenia. Schizophr Res 90:4145

Caligiuri A, Rosini E, D'arrigo P, Tessaro D, Molla G, Pollegioni L (2006b) Enzymatic conversion of unnatural amino acids by yeast D- amino acid oxidase. Adv Synth Catal 348:21832190

Caligiuri A, D'arrigo P, Gefflaut T, Molla G, Pollegioni L, Rosini E, Servi S (2006a) Multistep enzyme catalysed deracemisation of 2-naphthyl alanine. Biocatal Biotransfor 24:409-413

Chumakov I, Blumenfeld M, Guerassimenko O, Cavarec L, Palicio M, Abderrahim $\mathrm{H}$, Bouqueleret L, Barry C, Tanaka $\mathrm{H}$, La Rosa L, Puech A, Tahri N, CohenAkenine A (2002) Genetic and physiological data implicating the new human gene $G 72$ and the gene for Damino acid oxidase in schizophrenia. Proc Natl Acad Sci USA 99:367513680

Dib I, Stanzer D, Nidetzky B (2007) Trigonopsis variabilis $\mathrm{D}$-amino acid oxidase: control of protein quality and opportunities for biocatalysis through production in Escherichia coli. Appl Environ Microbiol 73:331-333

Erikson O, M Hertzberg, T Näsholm (2004) A conditional marker gene allowing both positive and negative selection in 
plants. Nat Biotechnol 22(4):455-458.

Gabler M, Fisher L (1999) Production of a new $D$-amino acid oxidase from the fungus Fusarium oxysporum. Appl Environ Microbiol 65:3750-3753

Garcia-Garcia M, Martinez-Martinez I, Sanchez-Ferrer A, Garcia-Carmona F (2008) Production of the apoptotic cellular mediator 4-methylthio-2oxobutyric acid by using an enzymatic stirred tank reactor with in situ product removal. Biotechnol Prog 24:187-191

Gupta N, Gundampati RK, Debnath M (2012) Screening of Novel Inducer for D-amino Acid Oxidase by Trigonopsis variabilis. Int $\mathrm{J}$ of Bioscience Biochem Bioinformat 2:200-2002

Hashimoto K, Fukushima T, Shimizu E, Komatsu N, Watanabe $H$, Shinoda N, Nakazato M, Kumakiri C, Okada S, Hasegawa H, Imai K, lyo M (2003) Decreased serum levels of $D$-serine in patients with schizophrenia: evidence in support of the $\mathrm{N}$-methyl-Daspartate receptor hypofunction hypothesis of schizophrenia. Arch Gen Psychiatry 60:572-576

Horner R, Wagner F, Fisher L (1996) Induction of the D-amino acid oxidase from Trigonopsis variabilis. Appl Environ Microbiol 62:2106-2110

Hwang TS, Fu HM, Lin LL, Hsu WH (2000) High-level expression of Trigonopsis variabilis D-amino acid oxidase in Escherichia coli using lactose as inducer. Biotechnol Lett 22:655-658

Khoronenkova SV, Tishkov VI (2008) DAmino Acid Oxidase: Physiological Role and Applications. Biochem 73:1511-1518

Kuan I, Liao R, Hsieh H, Chen K, Yu C (2008) Properties of Rhodotorula gracilis D-amino acid oxidase immobilized on magnetic beads through His-Tag. J Biosci Bioeng 105:110-115

Pollegioni L, Molla G (2011) New biotech applications from evolved D-amino acid oxidases. Trends Biotechnol 29:276-283

Lin SY, Wang JD, Lin JH (2009) Expression of Trigonopsis variabilis D-amino acid oxidase in transgenic rice for cephalosporin production. Botanical Stud 50:181-192
Maddess ML, Tackett MN, Ley SV (2008) Total synthesis studies on macrocyclic pipecolic acid natural products: FK506, the antascomicins and rapamycin. Progress in Drug Research 66:15-186

Massey V, Hemmerich P (1980) Active-site probes of flavoproteins. Biochem Soc Trans 8:246-257

Molla G, Vegezzi C, Pilone MS, Pollegioni L (1998) Overexpression in Escherichia coli of a recombinant chimeric Rhodotorula Gracilis D-amino acid oxidase. Protein Expr Purif 14:289-294

Patel RN (2001) Enzimatic synthesis of chiral intermediate for Omapatrilat, an anti-hypertensive drug. Biomol Eng $17: 167-182$

Patel RN (2001) Enzymatic synthesis of chiral intermediate for drug development. Adv Synth Catal 343:527-546

Pilone MS, Pollegioni L (2010) Enzymes, Damino acid oxidases in Encyclopedia of Industrial Biotechnology: Bioprocess, Bioseparation, and Cell Technology (Flickinger, M.C., ed.), pp. 1-11, John Wiley \& Sons

Plecko B, Hikel C, Korenke GC, Schmitt B, Baumgartner M, Baumeister F, Jakobs C, Struys E, Erwa W, Stockler-Ipsiroglu $S$ (2005) Pipecolic acid as a diagnostic marker of pyridoxine-dependent epilepsy. Neuropediatrics 36:200-205

Pollegioni L, Molla G, Sacchi S, Rosini E, Verga R, Pilone MS (2008) Properties and applications of microbial D-amino acidoxidases: current state and perspectives. Appl Microbiol Biotechnol 78:1-16

Pollegioni L, Piubelli L, Sacchi S, Pilone MS, Molla G (2007a) Physiological functions of D-amino acid oxidases: from yeast to humans. Cell Mol Life Sci 64:1373-1394

Pollegioni L, Sacchi S, Caldinelli L, Boselli A, Pilone MS, Piubelli L, Molla G (2007b) Engineering the properties of $D$-amino acid oxidases by a rational and a directed evolution approach. Curr Protein Pept Sci 8:600-618

Pollegioni L, Molla G, Sacchi S, Rosini E, Verga R, Pilone MS (2008) Properties and applications of microbial D-amino acid oxidases: current state and perspectives. Appl Microbiol 
Biotechnol 78:1-16

Prell A, Kujan P, Safar H, Holler $P$, Plhackova K, Sobotka A (2001) Damino acid oxidase an improved production of the enzyme by the yeast Trigonopsis variabilis in laboratory fermentor. Folia Microbiol 46:427-431

Rosini E, Pollegioni L, Ghisla S, Orru R, Molla G (2009) Optimization of Damino acid oxidase for low substrate concentrations towards a cancer enzyme therapy. FEBS J 276:4921-4932

Sacchi S, Rosini E, Molla G, Pilone MS, Pollegioni L (2004) Modulating Damino acid oxidase substrate specificity: production of an enzyme for analytical determination of all D-amino acids by directed evolution. Protein Eng Des Sel 17:517-525

Sacchi S, Bernasconi M, Martineau M, Mothet JP, Ruzzene M, Pilone MS, Pollegioni L, Molla G (2008) pLG72 modulates intracellular D-serine levels through its interaction with D-amino acid oxidase: effect on schizophrenia susceptibility. J Biol Chem 283:2224422256

Saleem A, Moharram AM, Fathy N (2012) Production and optimization of Damino acid oxidase which is involved in the biosynthesis of $\beta$-lactam antibiotics. African Journal of Microbiology Research 6:4365-4376

Bardaweel SK (2014) D-amino Acids:
Prospects for new therapeutic agents. J Med Bioeng 3:195-198

Simonetta PM, Verga R, Fretta A, Hanozet GM (1989) Induction of D-amino acid oxidase by $\mathrm{D}$-alanine in Rhodotorula gracilis grown in identified medium. Microbiology 135:593-600

Taylor PP, Pantaleone DP, Senkpeil RF, Fotheringham IG (1998) Novel biosynthetic approaches to the production of unnatural amino acids using transaminases. Trends Biotechnol 16:412-418

Tranchant C, Aubourg P, Mohr M, Rocchiccioli F, Zaenker C, Warter JM (1993) A new peroxisomal disease with impaired phytanic and pipecolic acid oxidation. Neurology 43:20442048

Tsai GE, Yang $P$, Chang YC, Chong MY (2006) D-Alanine added to antipsychotics for the treatment of schizophrenia. Biol Psychiatry 59:230234

Verrall L, Burnet PWJ, Betts JF, Harrison PJ (2010) The neurobiology of D-amino acid oxidase (DAO) and its involvement in schizoprenia. Mol Psychiatry 15:122-137

Zhao WJ, Gao ZY, Wei H, Nie HZ, Zhao Q, Zhou XJ, Wang YX (2010) Spinal Damino acid oxidase contributes to neuropathic pain in rats. J Pharmacol Exp Ther 332:248-254 